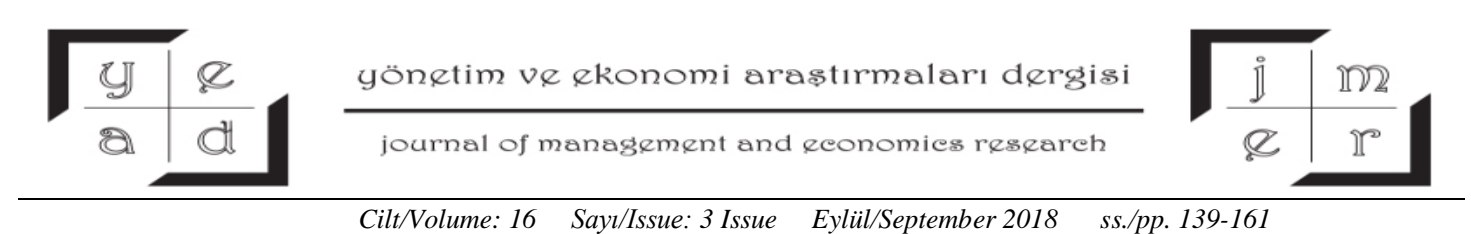

Y. Bilgin Doi: http://dx.doi.org/10.11611/yead.378145

\title{
OTEL İŞLETMELERİNDE HANGİ ÖRGÜT KÜLTÜRÜ PAZAR YÖNLÜLÜĞÜ DAHA FAZLA DESTEKLIYYOR?
}

\author{
Dr. Öğr. Üyesi Yusuf BíLGíN * id
}

\section{ÖZET}

Bu araştırmanın amacl, otel işletmelerinde hangi örgüt kültürünün pazar yönlülüğü daha fazla desteklediğini incelemektir. Araştırmada nicel araştırma yöntemi kullanılmış ve araştırma verileri, kolayda örnekleme yöntemiyle Türkiye 'de faaliyet gösteren beş yıldızl 20 otel işletmesinde görev yapan 355 personelden yüz yüze anketler yoluyla elde edilmiştir. Elde edilen veriler, yapısal eşitlik modellemesi (YEM) ile analiz edilmiştir. Analiz sonucunda, otel işletmelerinde örgüt kültürünün pazar yönlülük üzerinde anlamlı bir etkisinin olduğu belirlenmişstir. Elde edilen bulgular, otel işletmelerinde müşteri yönlülüğü en fazla destekleyen kültür tipinin adhokrasi kültürü olduğunu, rakip yönlülüğü ve fonksiyonlar arası koordinasyonu en fazla destekleyen kültür tipinin ise pazar kültürü olduğunu göstermektedir. Ayrıca, adhokrasi kültürünün rakip yönlülüğ̈̈ ve fonksiyonlar arası koordinasyonu hiyerarşi ve klan kültüründen daha fazla desteklediği tespit edilmiştir. Son olarak, analiz sonuçları hiyerarşi kültürünün müşseri yönlülük ve rakip yönlülük üzerinde anlamlı bir etkisinin olmadığını, fonksiyonlar arası koordinasyonu ise negatifyönlü etkilediğini göstermektedir.

Anahtar Kelimeler: Pazar yönlülük, örgüt kültürü, otel işletmeleri.

JEL kodu: M31, M14, L83

\section{WHICH ORGANIZATIONAL CULTURE SUPPORTS THE MARKET ORIENTATION MORE IN THE HOTEL BUSINESSES?}

\begin{abstract}
The aim of this study is to examine that which organization culture supports more market orientation in hotel businesses. A quantitative research method was used in the research and the research data were obtained through face-to-face surveys of 355 personnel that were working in twenty of 5-star hotels operating in Turkey by using convenience sampling method. Obtained data were analyzed by using Structural Equation Modeling (SEM). As a result of the analysis, it has been determined that the organizational culture has a significant influence on the market orientation in the hotel enterprises. Findings show that culture type which supports customer orientation most is culture
\end{abstract}

\footnotetext{
* Bayburt Üniversitesi, İ.İ.B.F., İşletme Bölümü, 69000, Bayburt, Türkiye e-mail: yusufbilgin@ bayburt.edu.tr
} 
of adhocracy however, competitor orientation and interfunctional coordination are the most supported by the market culture in the hotels. It has also been found that adhocracy culture supports competitor orientation and interfunctional coordination more than hierarchy and clan culture. Finally, the results of the analysis show that hierarchical culture has no significant effect on customer orientation and competitor orientation, and it affects the interfunctional coordination negatively.

Key Words: Market Orientation, Organizational Culture, Hotel Businesses.

JEL Codes: M31, M14, L83.

\section{Gİiș}

Günümüzde, Türk otel endüstrisi hızla değişen sosyal, ekonomik ve politik koşullara ve bilişim teknolojilerinin yaygın bir şekilde kullanımıyla daha bilinçli, zor tatmin olan ve farklı deneyimler arayan müşterilerin istek ve ihtiyaçlarına cevap vermede önemli zorluklarla karşı karşıyadır. Artan belirsizlik ve rekabet ortamı, varlığını ve karlılığını devam ettirmek isteyen otel işletmelerini mevcut müşterileri elde tutmaya ve yeni müşteriler cezbetmenin yollarını bulmaya zorlamaktadır. Müşteri tercihlerinin kolayca değişebildiği ve müşterileri için daha üstün değerler sunmaya hazır rakiplerin olduğu bir pazarda bunun anlamı, otel işletmelerinin pazar yönlü çalışmalara daha fazla önem vermeleri gerektiğidir.

Pazar yönlülüğün esası, müşterilerin şimdiki ve gelecekteki istek ve ihtiyaçlarını anlamaya ve bu istek ve ihtiyaçları rakiplerden daha üstün hizmet sunumuyla karşılamaya dayanmaktadır (Kohli ve Jaworski, 1990; Otache ve Mahmood, 2015). Hizmetin doğası gereği otel işletmelerinde üstün hizmet sunumu ancak bütün departmanların sürece etkin bir şekilde müşteri odaklı katılımlarıyla mümkündür. Çünkü otelin bir departmanında ortaya çıkan problemin müşteri memnuniyetini olumsuz etkilemesi diğer tüm departmanların üstün hizmet sunmak için gerçekleştirdikleri çabaları anlamsız kılabilmektedir. Bu noktada, bir işletmede üstün müşteri değerinin oluşturulmasında örgüt üyelerinin ve departmanların koordinasyonu için ihtiyaç duyulan bilgi ve deneyimlerin paylaşılması ve ortaya çıkan durumlar karşısında sergilenen tutum ve davranışlar o işletmenin sahip olduğu kültürle ilgilidir. $\mathrm{Bu}$ nedenle, örgütlerin müşterilerine ve çalışanlarına bakış açısını ve örgüt üyeleri arasındaki ilişkileri düzenleyen yazılı ve yazılı olmayan kuralları içeren örgüt kültürü (George, Sleeth ve Siders, 1999), işletmelerin üstün hizmet sunumunda önemli bir rol oynamaktadır. Başka bir ifadeyle, bir örgütün sahip olduğu kültür, örgütte üstün müşteri değeri yaratmak için gerçekleştirilen pazar yönlü uygulamaların başarısında etkilidir.

Aslında, pazar yönlülük Narver ve Slater (1990) tarafindan en etkili ve verimli bir şekilde üstün müşteri değeri yaratan örgüt kültürü olarak tanımlandığından beri pazar yönlülük ve örgüt kültürü arasındaki ilişkiler araştırmacılar için ilgi çekici bir konu olmuştur. Konuya ilişkin yapılan araştırmaların ortak noktası, hem örgüt kültürünün hem de pazar yönlülüğün işletme başarısının belirleyici unsurları 
olarak ele alınmalarıdır (Otache ve Mahmood, 2015; Jogaratnam, 2017). Araştırmacılar tarafindan elde edilen bulgular, otel işletmelerinde örgüt kültürünün (Asree, Zain ve Razalli, 2010; Han ve Verma, 2012) ve pazar yönlülüğün (Agarwal, Erramilli ve Dev, 2003; Sin, Tse, Heung ve Yim, 2005) işletme performansı üzerinde etkili olduğunu göstermektedir. Buna karşın örgüt kültürü ve örgütsel iklim gibi örgüt içi değişkenlerin pazar yönlülük üzerindeki etkisine ilişkin bulgular oldukça sınırlıdır (Jogaratnam, 2017). Örgüt kültürünün işletmelerin pazar yönlülüğünü etkilediği bakış açısıyla gerçekleştirilen araştırmalarda, pazar yönlülüğün kaynağını örgüt kültüründen aldığı ve örgüt kültürünün pazar yönlü davranışların işletme geneline yayılmasında enstrümantal bir rol oynadığ 1 kabul edilmektedir (Deshpande ve Webster, 1989; Egeren ve O’Connor, 1998; Matin, Jandaghi, Khanifar ve Heydari, 2009; Otache ve Mahmood, 2015; Cho, Kim, Park ve Cho, 2013). Bu nedenle, örgüt kültürü ve pazar yönlülük arasındaki etkileşimi anlamak daha fazla pazar yönlü olmak isteyen işletmeler için önemlidir (McClure, 2010). Bu araştırma otel işletmelerinde örgüt kültürünün pazar yönlülük üzerindeki etkisinin doğrudan incelenmesi açısından önemlidir.

$\mathrm{Bu}$ araştırmanın amacı, beş yıldızlı otel işletmeleri özelinde hangi örgüt kültürünün işletmelerin pazar yönlülüğünü daha fazla desteklediğini incelemektir. Bu doğrultuda, araştırma literatürü pazar yönlülük ve örgüt kültürü kavramları üzerine inşa edilmiştir. Daha sonra Rekabetçi Değerler Modelini (RDM) oluşturan örgüt kültürü tiplerinin otel işletmelerinin pazar yönlülükleri üzerindeki yansımaları incelenmiş ve araştırma hipotezleri temellendirilmiştir. Yöntem kısmında, araştırmanın evreni, örneklemi, veri toplama süreci ve veri analiz çerçevesi açıklanmıştır. Ardından araştırma verilerinin analizinden elde edilen bulgulara yer verilmiştir. Son olarak, bulgulardan hareketle ulaşılan sonuçlar açıklanmış ve araştırmacılar ve uygulayıcılar için öneriler sunulmuştur.

\section{TEORIK ÇERÇEVE VE HIPOTEZLERIN OLUŞTURULMASI}

\subsection{Pazar Yönlülük}

Literatürde pazar yönlülüğün pazarlama anlayışının uygulanması olduğu yaygın bir şekilde kabul edilmektedir (Kohli ve Jaworski, 1990; Narver ve Slater, 1990; Kosuge, 2007). Pazarlama anlayışını uygulayan bir işletmenin tüm faaliyetlerinin merkezinde müşteriler bulunmaktadır (Farrell, 2000). Örgütsel hedeflere ulaşmak için hedef pazardaki müşterilerin istek ve ihtiyaçlarını belirlemek ve onları rakiplerden daha etkin ve verimli bir şekilde tatmin etmek pazarlama anlayışının temelidir (Kotler, Armstrong, Saunders ve Wong, 1999:19). Pazar yönlülük ise örgütsel hedeflere ulaşmada müşteri ilişkileri geliştirmenin ve müşteri değeri yaratmanın pazarlama yöneticilerinin ve pazarlama departmanının fonksiyonel rollerinin ötesinde organizasyondaki herkesin görevi olduğunu vurgulamaktadır (Gray, Matear, Boshoff ve Matheson, 1998). Pazar yönlü işletmeler, hedef müşterilerin istek ve ihtiyaçları ve rakiplerin yetenekleri hakkında sürekli bir şekilde bilgi toplamaya ve sürekli üstün müşteri değeri yaratmak için bu bilgiyi kullanmaya odaklanmaktadır (Slater ve Narver, 1994). Bu noktada, pazar yönlülüğ̈̈ davranışsal açıdan ele alan Kohli ve Jaworski (1990) pazar yönlülüğün 
davranışsal bileşenlerini istihbarat sağlama, istihbaratı yayma ve cevap verme olarak ifade etmiştir. Kohli ve Jaworski'ye göre (1990: 6) pazar yönlülük, mevcut ve gelecekteki müşteri ihtiyaçları ile ilgili piyasa istihbaratının organizasyon çapında üretilmesi, bu istihbaratın departmanlar arasında yaygınlaştırılması ve kurum çapında yanıt verilmesidir. Bu yaklaşım, pazar yönlülügün işletmeler için işlevsel bir yapıya bürünmesine önemli katkı sağlamıştır (Pitt, Caruana ve Berthon, 1996). Bundan farklı olarak, Narver ve Slater (1990) pazar yönlülüğü kültürel perspektiften değerlendirmiş ve pazar yönlülüğün bileşenlerini müssteri yönlülük, rakip yönlülük ve fonksiyonlar arası koordinasyon olarak ifade etmiştir. Narver ve Slater (1990: 20) pazar yönlülüğü müşteriler için üstün değer yaratılması için gerekli davranışları en etkili ve verimli bir şekilde oluşturan böylece işletme için sürdürülebilir üstün performans sağlayan örgüt kültürü olarak tanımlamışlardır.

Müşterilerin ihtiyaç ve tercihleri hakkında bilgi edinmek ve yaymak için gerekli faaliyetleri içeren müşteri yönlülük, pazar yönlülüğün merkez unsurudur (Kohli ve Jaworski, 1990; Shoham, Rose ve Kropp, 2005). Narver ve Slater (1990) müşteri yönlülüğü, işletmenin müşterilerine sürekli bir şekilde üstün değer sunabilmek için onları yeterince anlaması olarak ifade etmiştir. Müşteri yönlülük, müşteriyi bütün karar süreçlerinde işletmenin bir parçası ve en üst otoritesi olarak görmektir (Civelek, 2016). İşletmeler hedef pazarlarındaki müşterilerin şimdiki ve gelecekteki istek ve ihtiyaçlarını ne kadar hızlı ve doğru keşfederlerse onlara o düzeyde üstün müşteri değeri sunma imkânına sahip olacaklardır. Böylece sunulan mal ve hizmetlerden memnun olan müşterilerin işletmeyi tekrar tercih etme ve diğer insanlara tavsiye etme eğilimleri artacaktır (Kandampully ve Suhartanto, 2000; Bowen ve Chen, 2001; Kim, 2007). Bir işletme için bunun anlamı, varlı̆ğını ve karlılığını devam ettirmektir. Literatürde müşteri memnuniyetinin ve müşteri sadakatinin işletme performansına pozitif yönlü yansıdığına ilişkin bulgular oldukça açıktır (Izquierdo, Cillán ve Gutierrez, 2005; Sin vd., 2005; Zhou, Brownve ve Dev, 2009; Wang, Chen ve Chen, 2012).

Dinamik bir çevrede, müşterilerin istek ve ihtiyaçlarını anlamak işletmelerin pazarlama eylemlerini ve stratejik hedeflerini daha açık tanımlamalarına olanak vermektedir (Pitt vd., 1996). Bunun ötesinde, rekabetçi bir iş çevresinde bir örgütün rekabet avantajı elde etmesi rakiplerinin ürünleri, fiyat politikaları, dağıtım ve tutundurma stratejileri hakkında sahip olduğu bilgi ile doğru orantılıdır (Otache ve Mahmood, 2015). Narver ve Slater (1990) pazar yönlülüğün diğer bileşeni olan rakip yönlülüğü, işletmenin şimdiki ve gelecekteki potansiyel rakiplerinin kısa vadedeki güçlü ve zayıf yönlerini, uzun vadede ise yetenek ve stratejilerini anlaması şeklinde tanımlamıştır. Pazardaki değişiklikleri ve pazar eğilimlerini doğru bir şekilde tahmin eden işletmeler hedef pazarlara daha üstün mal ve hizmetler sunarak müşterileri üzerinde daha yüksek bir satın alma niyeti ve daha fazla tatmin yaratabilirler (Fang, Chang, Ou ve Chou, 2014). Dolayısıyla rakiplere ilişkin doğrudan elde edilen bilgiler, müşteri istek ve ihtiyaçlarını rakiplerden daha hızlı karşılama ya da rakip eylemlerine zamanında yanıt vermede işletmeler için kritik bir başarı faktörüdür (Pulendran, Speed ve Widing, 2003; Plinke, 2015). 
Pazar yönlülüğün bir diğer bileşeni, fonksiyonlar arası koordinasyondur. Narver ve Slater (1990) fonksiyonlar arası koordinasyonu hedef müşteriler için üstün müşteri değerinin yaratılmasında işletme kaynaklarının kullanımının koordine edilmesi olarak ifade etmiştir. Hizmet işletmelerinde yalnızca pazarlama ya da herhangi bir departmanın gerçekleştirdiği pazar yönlü eylemler yetersizdir. Örneğin; bir otel işletmesinde misafirin konaklama deneyimi havuzun temizliğinden otopark hizmetlerine kadar uzanan geniş bir yelpazeden oluşmaktadır. Bu hizmet ağ içerisinde yer alan her çalışan ve departman üstün hizmet sunumunda birbirleri ile karşılıklı bağımlılık içerisindedir. İşletme personeli ya da departmanları arasında yaşanacak bir bilgi kirliliği, uyuşmazlık veya çatışmalar sunulan hizmet kalitesini kolayca zedeleyebilmektedir (Jaworski ve Kohli, 1993; Egeren ve O’Connor, 1998). Dolayısıyla işletmelerde üstün müşseri değeri yaratılması işletmenin tüm departmanları arasında müşteri istek ve ihtiyaçlarına cevap vermede gerekli eylemlerin koordinasyonu ile mümkündür (Kohli ve Jaworski, 1990). Tajeddini (2011) örgüt kültürlerinde fonksiyonlar arası koordinasyonu vurgulayan otellerin daha başarılı performans gösterdiklerini ortaya koymuştur.

\section{2. Örgüt Kültürü}

Örgütsel davranışın önemli bir bileşeni ve organizasyonel değişimin temel belirleyicilerinden olan kültür, otel işletmelerinde performansı etkileyen önemli bir faktördür (Dwyer, Teal ve Kemp, 1998; Agbejule, 2011; Wang vd., 2012). Yaygın olarak kabul edilen yaklaşımlarda örgüt kültürü, gözlemlenebilir özelliklerine odaklanılan bir değişken ya da organizasyonda var olan fakat her zaman gözlemlenemeyen süreç temelli bir metafor olarak kabul edilmektedir (Smircich, 1983; Deshpande ve Webster, 1989). Hangi açıdan bakılırsa bakılsın örgüt kültürü, bir örgütün tasarımından insan ilişkilerine örgütsel kararlardan müşterilerle olan ilişkilere kadar organizasyonun bütün yönleriyle ilgilidir (Youngblood, 2000). Camerer ve Vepsalainen (1988) örgüt kültürünün beklenmeyen iş durumları altında çalışanlara ne yapmaları gerektiğini söyleyen geniş ve örtük bir felsefeyi ve kuralları içerdiğini ifade etmiştir. Deshpande ve Webster (1989) örgüt kültürünü, bireylerin örgütsel işleyişi anlamalarına yardımcı olan, böylece onlar için örgütsel davranış kalıpları oluşturan paylaşılan değer ve inançlar dizisi olarak tanımlamıştır. Örgüt kültürü, üyelerin tutum ve davranışları ile işletme amaçlarının uyumluluğuna (Kilman, 1985), üyeler arasında iletişimin etkinliğine (Gagliardi, 1986) ve üyeler ve yöneticiler arasında paylaşılan değerler, inançlar ve normlar üzerinde etkilidir. Dolayısıyla bir işletmenin sahip olduğu kurum kültürü, işletmenin pazar yönlülüğü (Kosuge, 2007; Shehu ve Mahmood, 2014; Otache ve Mahmood, 2015) ve finansal performansı üzerinde etkilidir (Denison, 1984; Camerer ve Vepsalainen, 1988; Cho vd., 2013).

Literatürde örgüt kültürünün örgütsel etkinliğe yansımaları örgütsel davranışla ilgilenen araştırmacılar tarafından sıklıkla incelenen bir konudur. Bu ilişkiyi analiz etmede en yaygın ve etkili şekilde kullanılan analitik araçlardan birisi Quinn ve Rohrbaugh (1983) tarafından ortaya konulan Rekabetçi Değerler Modelidir (RMD). Başlangıçta birbirlerinden bağımsız geliştirilen örgütsel etkinlik 
modellerini bütünleştirmek için bir üstkuram olarak ortaya atılan (Quinn ve Cameron, 1983) ve sonrasında Cameron ve Quinn (1999) tarafindan revize edilen RDM, örgütsel araştırmalar için oldukça işlevsel bir genel çerçeve sunmaktadır (Dastmalchian, Lee ve Ng, 2000). Cho ve diğerlerine (2013) göre farklı örgüt kültürü tipleri örgütün yönetimindeki doğal ilişkilere ve karşıtlıklara odaklanırken rekabetçi değerler modeli birbirleriyle uyumsuz görünen çeşitli rekabetçi değerleri ve hedefleri dengeleyebilen bir modeldir. Rekabetçi değerler modelinde örgüt kültürü tipleri sırasıyla klan, adhokrasi, pazar ve hiyerarşi olarak isimlendirilmektedir (Cameron ve Quinn, 2006: 36). Şekil 1'de rekabetçi değerler modelini oluşturan boyutlar gösterilmektedir.

Klan kültürüne sahip örgütlerde yöneticiler bir baba ya da danışman rolüne sahiptirler. Örgüt içi ilişkiler bir aile gibi işlediğinden bu kültürün tipik özellikleri örgütsel bağl1lık, güven ve takım çalışmasıdır. Bu kültüre sahip örgütlerde organizasyon dışı gelişmeler ve kontrol gibi konular yerine içsel konular ve değerlere, esneklik ve takdir konularına yoğunlaşılmaktadır (Taşgit, Ergün ve Bayat, 2015). Adhokrasi kültürünün temel amacı, çevresel belirsizlik karmaşıklık ve bilgi bombardımanı olduğunda örgütün bu türbülansa karşı esnekliğini, yaratıcılığını ve adaptasyonunu hızlandırmaktır (Cameron ve Quinn, 2006: 43). Adhokrasi kültüründe örgütü bir arada tutan unsur girişimciliğe ve yenilikçiliğe bağl11ıktır. Bu bağl11ık, yenilik ve yaratıcılıkta bireysel inisiyatif alma ve özgürlügü teşvik ederek örgütün dış çevreye uyumunu kolaylaştırmakta ve rekabetçiliği desteklemenin yolu olarak görülmektedir (Rodrigues ve Caetano, 2013).

\section{Şekil 1. Rekabetçi Değerler Modeli}

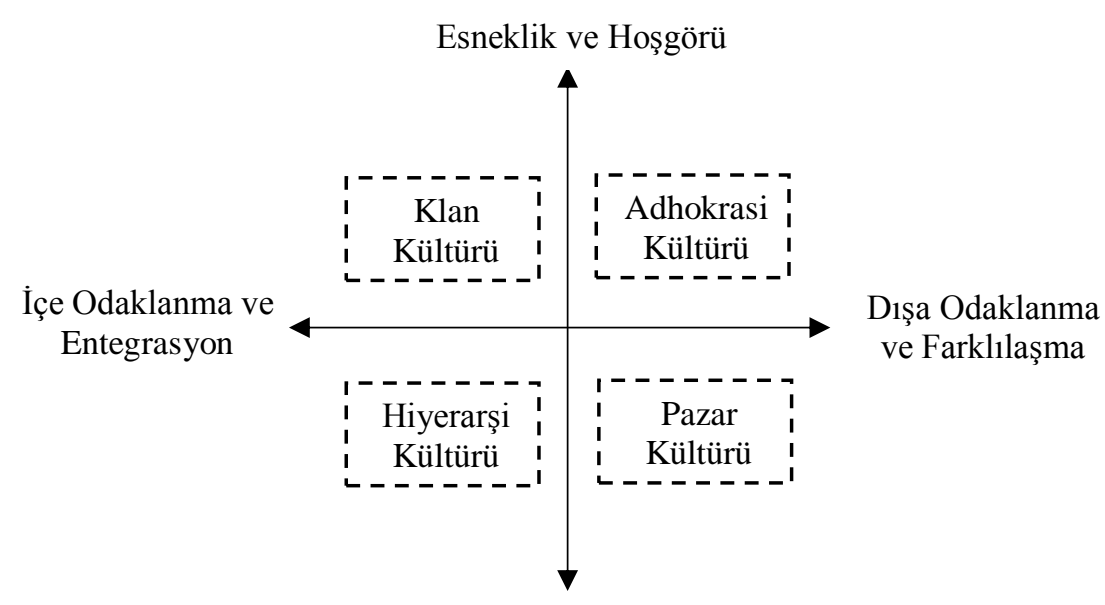

Kararll11k ve Kontrol

Hiyerarşi kültürü, oldukça resmi ve yapısal ilişkilere dayandırılan bir çalışma ortamını ifade etmektedir. Organizasyonu bir arada tutan resmi kurallar ve politikalardır (Dastmalchian vd., 2000). Belirlenen hedefi tamamlama ve görev üretkenliği üzerine odaklanan rasyonel kültürde örgüt üyelerinden beklenen kendilerine tanımlanan görevleri en verimli şekilde yerine getirmeleridir (Cho vd., 2013). Pazar kültürü, örgütün içsel süreçlerinden ziyade müşteriler, rakipler ve tedarikçiler gibi dış paydaşlarına odaklanmaktadır. Pazar kültüründe başarı, pazar payı ve pazara nüfuz etme düzeyi açısından ölçülmektedir (Dastmalchian vd., 2000). Liderler işlerin yürütülmesi konusunda katı ve 
tutkuludur. Çalışanların rekabetçi ve amaç odalı olduğu bu kültürde örgütü bir arada tutan unsur kazanmaya verilen önemdir.

\subsection{Hipotezlerin Geliştirilmesi}

Pazarlama anlayışı, müşteriyi stratejinin ve operasyonların merkezine yerleştiren temel bir inanç ve değerler setinin paylaşıldığı bir kültürdür (Deshpande ve Webster, 1989). Bu kültür, müşteri ve işletme arasındaki ilişkileri geliştirmeye odaklanan bir örgütte paylaşılan değerlerin ve üyelerin müşterilerin çıkarlarını korumaya yönelik inançlarının bir yansımasıdır (Jogaratnam, 2017). Somut ürünlerden farklı olarak, hizmetin sunumu sürecinde üyelerin tutum ve davranışları müşterilerin hizmet deneyimlerini şekillendirdiğinden (Lehtinen ve Lehtinen, 1991) örgüt kültürü, hizmetlerin kalitesinde belirleyici bir rol oynamaktadır. Çünkü hizmetin üretimi ve tüketimi eşzamanlıdır ve hizmet kalitesinin değerlendirilmesinde hizmetin sonucu kadar süreci de önem taşımaktadır (Parasuraman ve diğ., 1985). Bu noktada, örgüt kültürü, üyelerin davranışlarına rehberlik etmekte, onları şekillendirmekte (Cheung, Wong ve Wo, 2011) ve örgütsel davranışın tutarlılığını desteklemektedir (Louis, 1980). Dahası çalışanlar organizasyona misafirlerden geri bildirim sağladıklarından pazar bilgisinin elde edilmesinde kritik bir role sahiptirler (Kim vd., 2017). Bu bilginin örgüt içinde paylaşımı ve müşteriler için değer üretecek şekilde kullanımı ise yine örgütün sahip olduğu kültürle yakından ilişkilidir. Dolayısıyla pazar odaklı olmak isteyen bir işletme, hedef pazarının istek ve ihtiyaçlarını belirleyerek sürdürülebilir rekabet avantajı elde etmek için üstün müşteri değeri yaratacak bir iş kültürünü benimsemelidir (Tsiotsou, 2010). Literatürde örgüt kültürünün işletmelerin pazar yönlülükleri üzerinde anlamlı bir etkiye sahip olduğuna ve bu etkinin örgüt tiplerine göre farklılaşabildiğine ilişkin bulgular bulunmaktadır (Appiah-Adu ve Blankson, 1998; Matin vd., 2009; Shehu ve Mahmood, 2014). Bu araştırmada, örgüt kültürünün otel işletmelerinin pazar yönlülüğü üzerindeki etkisi rekabetçi değerler modelinde yer alan kültür tipleri ile Narver ve Slater (1990) tarafindan ortaya konulan pazar yönlülük bileşenleri açısından ele alınmıştır. Bu noktada, bu dört örgüt kültürü tipinin kuruluşlarda birbirinden heterojen bir özellik göstermeksizin bir karışım haline gelebildiği göz önünde bulundurulması gereken bir husustur. Öz, Kaya ve Çiftçi (2015) İstanbul' daki 5 yıldızlı otel işletmelerinin örgüt kültürlerini rekabetçi değerler modeli üzerinden incelemiş ve kültür tipleri arasında belirgin bir farkın olmadığını tespit etmişlerdir.

İlk olarak, müşteri yönlülük, işletmelerin üstün hizmet sunarak yaşam boyu müşteri değeri elde etmesini sağlayacak pazarlama stratejileri tasarlaması ve uygulaması için gerekli bilgileri edinmesi ve özümsemesidir (Brady ve Cronin, 2001). Pazar kültürü ve adhokrasi kültürü dış çevreye odaklanan bir anlayışa sahip olduklarından müşterilerin istek ve ihtiyaçlarına ilişkin kritik pazar bilgisinin elde edilmesinde klan ve hiyerarşi kültür tiplerine göre daha etkindirler. Ancak örgütte müşteri yönlülüğü yoğun bir şekilde destekleyecek ve benimsetecek muhtemel değerleri ve inançları dikkate almadan basit bir şekilde, müşterilerin istek ve ihtiyaçları hakkındaki bilgiye odaklanmak yeterli değildir (Deshpande, Farley ve Webster, 1993). Bu noktada, yenilikçilik, girişimcilik ve risk almaya odaklı bir kültür olan 
adhokrasi kültürü müşteri yönlülüğü pazar kültüründen daha fazla desteklemektedir. Çünkü adhokrasi kültürünün girişimcilik özelliği, müşterilerin mevcut ve gelecekteki istek ve ihtiyaçlarını anlamayı ve yeni ürün ve hizmetler geliştirmeyi kolaylaştıırken (Cameron ve Quinn, 1999) liderlerin başarısızlıkları müsamaha düzeyi ve öğrenmeyi teşvik etmesi hizmet sunum sürecinde çalışanların ortaya çıkabilecek durumlar karşısında sorumluluk almalarını desteklemektedir. Pazar kültüründe ise iş bitiriciliğe ve kazanmaya yapılan vurgu (Cameron ve Quinn, 1999) çalışanların uzun vadede müşteri değeri yerine kısa vadeli kazanımlara öncelik vermeleriyle sonuçlanabilir. Hiyerarşi kültürü ve klan kültürü, çevresel değişimlere karşı daha az duyarlı olduğundan müşteri istek ve ihtiyaçlarını takip etmede adhokrasi ve pazar kültürüne göre yetersizdirler (Appiah-Adu ve Blankson, 1998). İki kültür kıyaslandığında, organizasyonun başarısının müşterilere karşı duyarlılık açısından değerlendirildiği klan kültürü, başarının işlerin prosedürlere uygun yapılma derecesi ve düşük maliyet ile karakterize edildiği (Adler ve Borys, 1996; Dastmalchian vd., 2000) hiyerarşi kültüründen daha müşteri yönlüdür. Çünkü klan kültüründe çalışanların gelişimine ve motivasyonuna verilen destek (Lund, 2003) ve hizmet sunumunda kendi inisiyatif ve yaratıcılıklarını kullanmaları (Daft, 2015:345) hizmet kalitesi düzeyinin artırılmasında doğrudan etkilidir. Bu doğrultuda oluşturulan araştırma hipotezleri sırasıyla aşağıda ifade edildiği gibidir:

H1 $1_{\mathbf{a}, \mathbf{b}, \mathbf{c}, \mathbf{d}}$ : “Otel işletmelerinde örgüt kültürü; a) adhokrasi kültürü, b) pazar kültürü, c) klan kültürü, d) hiyerarşi kültürü müşteri yönlülüğü etkilemektedir.”

Rakip yönlülük, işletmelerin rakip eylemlerine cevap vermek ve onlardan daha üstün hizmet sunabilmek için pazar istihbaratı toplamanın yanı sıra müşterilerin istek ve tercihlerini etkileyen rekabet ve düzenlemeler gibi pazar dinamiklerine odaklanmasıdır (Narver ve Slater, 1990; Kohli ve Jaworski, 1990). Bu, örgüt kültürünün dış çevreye adaptasyonu ve işletmenin yakın ve uzak çevredeki değişimlere ve koşullara duyarlılığ ve etkili bir şekilde karşıllı verebilme düzeyi ile ilgilidir (Schein, 1990). Bu bakımdan, otel endüstrisi gibi rekabetçi bir piyasada, pazar kültürünün farklılaştırma, pazar liderliği ve rekabet avantajı gibi karakteristik özellikleri işletmelerin rakip yönlülügünü diğer kültür tiplerinden daha fazla desteklemektedir (Appiah-Adu ve Blankson, 1998; Harrington ve Guimaraes, 2005). Pazar kültürünü yenilikçilik ve girişimcilik gibi özellikleri ile karmaşık pazar koşullarına cevap verebilmek için firsat ve avantaj aramaya yönelik davranışlara vurgu yapan (Cameron ve Quinn, 1999; Lund, 2003) adhokrasi kültürü izlemektedir. Bu kültür tiplerinin aksine hiyerarşi kültüründe örgüt uzun vadede istikrar, öngörülebilirlik ve etkililik ile ilgilenmektedir (Dastmalchian vd., 2000). Yani, hiyerarşi kültürünün baskın olduğu işletmelerde değişime karşı direnç vardır ve bu işletmeler çevresel değişimlere karşı daha az duyarlıdır (Fiol ve Lyles, 1985). Dolayısıyla hiyerarşi kültürü, rakip yönlülügü pazar ve adhokrasi kültürüne göre daha az desteklemektedir. Rakip yönlülüğü en az destekleyen örgüt kültürü ise organizasyon dışı gelişmeler ve kontrol gibi konular yerine insan kaynaklarını geliştirme, bağl1lık, takım çalışması gibi konulara (Cameron ve Quinn, 1999) vurgu yapılan klan kültürüdür. Deshpande ve diğerleri (1993) klan kültürünün örgüt içi süreçlere ve geleneklere olan bağlılığının değişen pazar 
koşullarına odaklanılmada önemli eksikliklere neden olduğunu belirtmiştir. Bu bağlamda ortaya konulan hipotezler şu şekildedir:

$\mathbf{H 2} \mathbf{2}_{\mathbf{a}, \mathbf{b}, \mathbf{c}, \mathbf{d}}$ " “Otel işletmelerinde a) pazar kültürü b) adhokrasi kültürü, c) hiyerarşi kültürü, d) klan kültürü rakip yönlülüğ̈̈ etkilemektedir.”

Fonksiyonlar arası koordinasyon müşterilere daha kaliteli hizmet sunabilmek için örgüt içinde bilgi ve kaynakların iletişimi ve paylaşımı, farklı departmanların entegrasyonu ve işbirliği düzeyini ifade etmektedir (Peng ve George, 2011). İşletmelerde fonksiyonlar arası koordinasyonun sağlanması, her departmanın kendi etkinliğini artırmak için diğer departmanlarla yakın işbirliği kurmasını sağlayacak teşviklerin uyumlaştırılması ve işlevsel bağlılık yaratılması yoluyla gerçekleştirilebilir (Narver ve Slater, 1990). Otel işletmeleri müşterilerine konaklamadan hediyelik eşya satışı hizmetlerine kadar uzanan holistik bir deneyim sunduklarından departmanlar arası bağlılık düzeyi oldukça yüksektir. Ancak hizmetin sunumu sürecinde yaşanması muhtemel bir bilgi eksikliği ya da herhangi bir departmanın müşteri beklentilerini karşılayamaması üstün hizmet sunumunda diğer departmanların çabalarını boşa çıkarabilmektedir. Bu nedenle etkili fonksiyonlar arası koordinasyon tüm departmanların müşteri istek ve ihtiyaçlarına aşırı hassasiyet göstermelerini ve diğer departmanlarla ilişkilerini bu hassasiyet üzerine inşa etmelerini gerektirmektedir (Jayawardhana, Silva ve Athauda, 2013). Örgüt kültürü tipleri açısından düşünüldügünde fonksiyonlar arası koordinasyonu en fazla destekleyen örgüt kültürü, takım çalışması, katılım ve uyum gibi karakteristik özelliklerinden ötürü klan kültürüdür.

Fonksiyonlar arası koordinasyonda klan kültürünü, diğer içsel süreçlere odaklı örgüt kültürü olan hiyerarşi kültürü izlemektedir. Hiyerarşi kültürünün merkezi karar verme, kurallar ve prosedürler, kontrol ve sorumluluk anlayışı gibi karakteristik özellikleri, onu örgüt dışı değişkenlere odaklanan adhokrasi ve pazar kültürünün önüne geçirmektedir. Her ne kadar hiyerarşi kültürüne sahip örgütler yüksek düzeyde formelleşme, uzmanlaşma ve esneklikten yoksunluk gibi özelliklere sahip olsalar da (Adler ve Borys, 1996) bu özellikleri aşmada yüksek düzeyde tutarlılık, uyumluluk ve işbirliği gibi karakteristik nitelikler (Daft, 2010: 345) örgütlerin belirsizliğin ortaya çıkardığı karmaşadan sakınmasında ve çalışanların görevlerini daha verimli bir şekilde yerine getirmelerinde etkilidirler (Lawrence ve Lorsch, 1967). Adler ve diğerleri (1999) hiyerarşik yapıların bu özelliklerden dolayı bugünün dinamik iş ortamında dahi, hala yüksek örgütsel verimliliği sağladığını ifade etmişlerdir. Adhokrasi kültürü, örgüt içinde stabilite ve control yerine bireysel inisiyatif alma ve özgürlügü teşvik etmektedir (Cameron ve Quinn, 1999). Bireyselliğin ve özgürlüğün teşvik edildiği ve kontrol düzeyinin sınırlı olduğu bir çalışma ortamında fonksiyonlar arası koordinasyonun klan kültürü ve hiyerarşi kültürüne göre daha zayıf olması beklenmektedir. Fonksiyonlar arası koordinasyonu en zayıf bir şekilde destekleyen örgüt kültürü ise organizasyonel esneklik, pazardaki rekabetçi pozisyonunun iyileştirilmesi, pazara nüfuz etme ve pazar payı (Harrington ve Guimaraes, 2005) gibi dışa dönük karakteristik özelliklerinden ötürü pazar kültürüdür. Bu doğrultuda araştırma hipotezleri sırasıyla aşağıdaki gibi oluşturulmuştur. 
$\mathbf{H 3}_{\mathbf{a}, \mathbf{b}, \mathbf{c}, \mathbf{d}}$ : “Otel işletmelerinde a) klan kültürü, b) hiyerarşi kültürü, c) adhokrasi kültürü, d) pazar kültürü fonksiyonlar arası koordinasyonu etkilemektedir."

\section{YÖNTEM}

$\mathrm{Bu}$ araştırmanın amacı, otel işletmelerinde hangi örgüt kültürünün pazar yönlülüğü daha fazla etkilediğini incelemektir. Araştırmanın değişkenleri ve değişkenler arasındaki ilişkilerin testi için önerilen araştırma modeli şekil 1'de gösterildiği gibidir.

\section{Şekil 1. Araştırma Modeli}

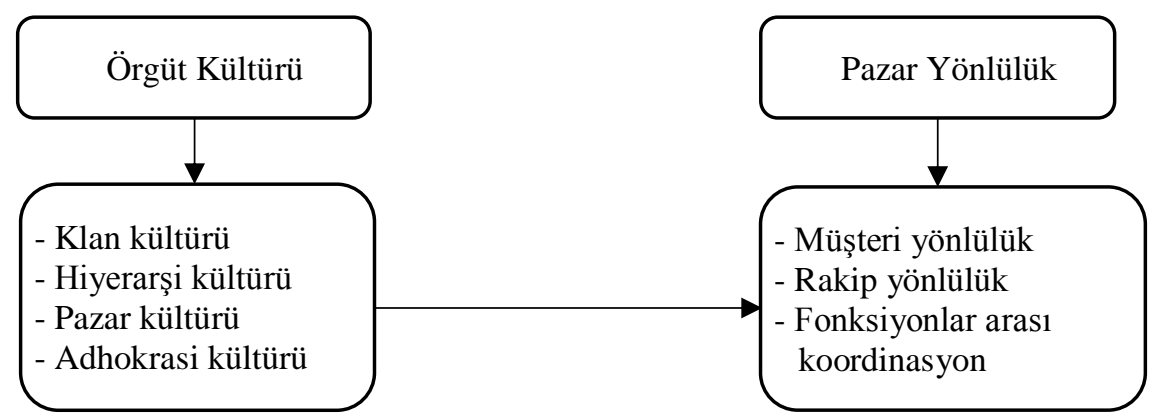

Araştırmanın evrenini, Türkiye'de faaliyet gösteren 685 beş yıldızlı otel işletmesi oluşturmaktadır. Uygulama alanı olarak, beş yıldızlı otel işletmelerinin seçilmesinin nedeni otel işletmelerinde kurumsallık düzeyinin ve pazarlama uygulamalarının yıldız sayısıyla doğru orantılı olmasıdır (Eren, 2003; Bilgin, Çatı ve Öncü, 2016). Evreni oluşturan işletmelerin coğrafi olarak geniş bir alana yayılmış olmaları ve araştırmaya katılmadaki isteksizliklerinden ötürü araştırmada kolayda örnekleme tekniği kullanılmıştır.

Araştırma verileri, anket tekniği kullanılarak elde edilmiştir. Araştırma anketi üç kısımdan oluşmaktadır. Birinci kısımda, otel işletmelerinin pazar yönlülüklerini ölçmeye yönelik 15 ifade yer almaktadır. Narver ve Slater (1990) tarafindan ortaya konulan bu ölçüm modelinin otel işletmelerinde pazar yönlülüğünün ölçümünde kullanıldığı araştırmalar bulunmaktadır (Zhou vd., 2009; Tajeddini, 2011). İkinci kısımda, otel işletmelerinin örgüt kültürünü değerlendirmek için Cameron ve Quinn (2006: 26-29) ifade edilen Örgütsel Kültür Değerlendirme Aracı'nda (Organizational Culture Assessment Intrument- OCAI) yer alan 24 ifade kullanılmıştır. Bu ifadeler, rekabetçi değerler modelinde yer alan örgüt tiplerinin baskın özellikler, örgütsel liderlik, çalışanların yönetimi, örgütün birlikteliği, stratejik vurgu ve başarı kriterleri açısından değerlendirilmesini içermektedir. OCAI, bir kuruluşta her bir kültür türünün temsil edilme derecesini organizasyonun her düzeyinde maksimum katılımını kolaylaştırarak üyelerin bireysel değerlendirmeleri yoluyla ölçmektedir. Literatürde otel işletmelerinde örgüt kültürünün OCAI kullanılarak değerlendirildiği araştırmalar bulunmaktadır (Mushtaq, Fayyaz ve Tanveer, 2013; Taşgit vd., 2015). Otel işletmelerinde pazar yönlülük ve örgüt kültürü ölçüm modellerinde beşli likert tipi (1=Kesinlikle katılmıyorum, 5=Kesinlikle katıllyorum) ölçek kullanılmıştır. Ölçeğin son kısmında, katılımcıların demografik özelliklerine ve otel işletmelerinin karakteristik özelliklerine ilişkin kapalı uçlu sorular bulunmaktadır. 
Araştırma ölçeğinin oluşturulmasının ardından beş yıldızlı 3 otel işletmesinden elde edilen 57 veriye güvenilirlik analizi uygulanmıştır. Güvenilirlik analizi sonucunda, ölçekte yer alan tüm ifadeler için Cronbach' Alpha değerinin 0.91 çıkması araştırma ölçeğinin oldukça güvenilir olduğunu göstermektedir (Kalaycı, 2016:405). Gerçekleştirilen ön testin ardından evrende yer alan her bir işletmeye araştırmanın amacını ifade etmek ve desteklerini alabilmek amacıyla mail ya da telefon yoluyla ulaşılmıştır. Bu süreçte, 100'den fazla beş yıldızlı otel işletmesinden pozitif dönüş olmasına rağmen bu işletmelerin büyük bir kısmı veri toplama sürecini desteklememiştir. Araştırmanın verileri, 11 Nisan 2017-22 Eylül 2017 tarihleri arasında 20 beş yıldızlı otel işletmesinin ön büro, pazarlama, insan kaynakları ve yiyecek içecek departmanlarında görev yapan 355 personelden yüz yüze anket uygulaması yoluyla elde edilmiştir. Ek 1'de araştırma verilerinin elde edildiği beş yıldızlı otel işletmeleri listelenmektedir. Araştırma verilerinin analizinde sırasıyla otel işletmelerine ve katılımcılara ilişkin bilgileri değerlendirmek için frekans analizleri, ölçüm modellerini test etmek için Açıklayıcı ve Doğrulayıcı Faktör Analizi ve değişkenler arasındaki ilişkileri saptamak için Path analizi kullanılmıştır.

\section{BULGULAR}

\subsection{Katılımcıların ve İşletmelerin Karakteristik Özellikleri}

Araştırmaya katılan otel çalışanlarının 168'i kadın ve 187'si erkektir. Katılımcılardan 277'sinin yaş1 35 'in altındadır ve 45 yaş ve üzerine sahip 11 katılımcı bulunmaktadır. Katılımcıların eğitim seviyeleri incelendiğinde; 98'i lise ve altı düzeyde eğitime, 110'u ön lisans düzeyinde eğitime ve 135'i lisans düzeyinde eğitime sahiptir. Katılımcılardan yalnızca 12'si ise lisansüstü düzeye eğitime sahiptir. Katılımcıların 121'i pazarlama departmanında, 120'si ön büro departmanında ve 114'ü yiyecek-içecek departmanında görev yapmaktadır. Otel işletmelerine ilişkin tanımlayıcı istatistikler incelendiğinde ise sahiplikleri açısından otel işletmelerinden 13'ü özel mülkiyetli otel işletmesi, 4'ü ulusal zincir otel işletmesi ve 3'ü uluslararası zincir otel işletmesidir. Otel işletmelerinin 7'si iş müşteri tipine, 5'i tatil müşteri tipine ve 8'i ise bu müşteri segmentlerinin ikisine de hizmet vermektedir. Tablo 1'de katılımcıların ve otel işletmelerinin karakteristik özellikleri gösterilmektedir.

Tablo 1. Katılımcıların ve Otel İşletmelerinin Karakteristik Özellikleri

\begin{tabular}{|c|c|c|c|c|c|}
\hline Katılımcılar & Frekans & Yüzde \% & Oteller & Frekans & Yüzde \% \\
\hline Cinsiyet & & & Otel Sahiplikleri & & \\
\hline Erkek & 158 & 44.5 & Özel mülkiyet & 13 & 65 \\
\hline Kadın & 197 & 55.5 & Ulusal zincir otel & 4 & 20 \\
\hline Yaş & & & Uluslararas1 zincir otel & 3 & 15 \\
\hline 25’ten küçük & 101 & 28.5 & Müşteri Tipi & & \\
\hline $26-35$ & 176 & 49.6 & İş & 7 & 35 \\
\hline $36-45$ & 67 & 18.9 & Tatil & 5 & 25 \\
\hline 45 'ten büyük & 11 & 3.1 & Her ikisi de & 8 & 40 \\
\hline \multicolumn{6}{|l|}{ Eğitim Düzeyi } \\
\hline Lise ve alt1 & 98 & 27.6 & & & \\
\hline Ön lisans & 110 & 31.0 & & & \\
\hline Lisans & 135 & 38.0 & & & \\
\hline
\end{tabular}




\begin{tabular}{lcc}
$\begin{array}{l}\text { Yüksek lisans } \\
\text { Departman }\end{array}$ & 12 & 3.4 \\
\hline Pazarlama & 89 & 25.1 \\
Ön büro & 93 & 26.2 \\
Yiyecek-İçecek & 82 & 23.1 \\
İnsan kaynakları & 91 & 25.6 \\
\hline
\end{tabular}

\subsection{Açıklayıcı Faktör Analizi}

Otel işletmelerinde örgüt kültürü tiplerinin pazar yönlülüğe etkisini incelemek için ilk olarak, oluşturulan ölçüm araçlarının yapı geçerliliği Açıklayıcı Faktör Analizi (AFA) yoluyla test edilmiştir. Veri setinin AFA için uygunluğunu test etmek amacıyla elde edilen verilerin KMO ve Barlett testi değerleri incelenmiştir. Örgüt kültürü (KMO .932 ve Barlett testi $\chi 2$ değeri 4516.014, p< .000) ve pazar yönlülüğe (KMO .922 ve Barlett testi $\chi^{2}$ değeri 2817.887, p<.000) ilişkin elde edilen değerler, veri setinin AFA için uygun olduğunu göstermektedir (Kalayc1, 2016: 322).

AFA'da faktör öz değerinin en az 1, faktör yükünün en az 0.50 ve iki faktör altında yer alan ifadelerin faktör yükleri arasında en az .10 fark olması dikkate alınmıştır. İlk olarak, örgüt kültürü ölçüm modelinde yer alan verilere AFA uygulanmıştır. Örgüt kültürü ölçüm modeline ilişkin veriler AFA'da Principal Components ve Rotation-Varimax döndürme yöntemi kullanılarak analiz edilmiştir. Analiz sonucunda, örgüt kültürü verileri toplam varyansın \% 74.400'ünü açıklayan 4 boyut altında toplanmıştır. Ortaya çıkan faktör yapısında tüm ifadelerin faktör yükleri .755 ile .932 arasında değişmektedir. Örgüt kültürünü oluşturan faktörlerin güvenilirlik düzeyleri ise .90 ve .96 arasındadır. Daha sonra pazar yönlülüğe ilişkin verilere AFA uygulanmıştır. Pazar yönlülük ölçüm modeline ilişkin veriler Principal Components ve Rotation-Varimax döndürme yöntemi kullanılarak test edilmiştir. Veri setinde yer alan tüm ifadeler toplam varyansın \% 68.636'sını açıklamaktadır. Bu boyutlar altında yer alan ifadelerin faktör yükleri .705 ile .831 arasında ve güvenilirlik düzeyleri .86 ve .90 arasındadır. Açıklayıcı faktör analizi sonucunda, hem pazar yönlülük hem de örgüt kültürü ölçüm modellerinde yer alan tüm gözlenen değişkenler belirlenen kriterlere uyumlu çıkmıştır.

\subsection{Doğrulayıcı Faktör Analizi}

Otel işletmelerinde örgüt kültürü ve pazar yönlülük ölçüm modellerine ilişkin AFA'da ortaya konulan yapının doğruluğunu test etmek amacıyla AFA sonuçlarına göre düzenlenmiş verilere Doğrulayıcı Faktör Analizi (DFA) uygulanmıştır. Doğrulayıcı Faktör Analizi (DFA) yoluyla araştırmanın değişkenlerine ilişkin belirlenen yapının mevcut verilerle ne derece doğrulandığı incelenmiştir. Tablo 2' de DFA sonuçları gösterilmektedir. 
Tablo 2. Bütün Yapıya İlişsin Doğrulayıcı Faktör Analizi ve Uyum Geçerliliği Sonuçları

\begin{tabular}{|c|c|c|c|}
\hline Yapı/ Değiş̧kenler/İfadeler & $\begin{array}{r}\text { Standart } \\
\text { yükler }\end{array}$ & $\begin{array}{c}\text { Bileşik } \\
\text { güvenirlik } \\
>0.6\end{array}$ & $\begin{array}{l}\text { AVE } \\
>0.5\end{array}$ \\
\hline \multicolumn{4}{|l|}{ Pazar Yönlülük } \\
\hline Müșteri yönlülük & & 0.89 & 0.57 \\
\hline Müşteriye verilen sözleri yerine getirmek için çaba sarf edilmesi & $0.77 * *$ & & \\
\hline Müșteri değeri yaratmak için sürekli çalıșmalar yapılması & $0.82 * *$ & & \\
\hline Müşteri istek ve ihtiyaçlarını anlamak için sürekli bilgi toplanması & $0.78 * *$ & & \\
\hline $\begin{array}{l}\text { Müssteri memnuniyeti hedefini yerine getirmek için çaba sarf } \\
\text { edilmesi }\end{array}$ & $0.75^{* *}$ & & \\
\hline Müşteri memnuniyetinin sürekli ölçülmesi & $0.70 * *$ & & \\
\hline Satış sonrası hizmetleri en iyi şekilde vermek için gayret gösterilmesi & $0.74 * *$ & & \\
\hline Rakip yönlülük & & 0.86 & 0.60 \\
\hline Çalışanların rakiplerle ilgili bilgileri birbirleriyle paylaşmaları & $0.78 * *$ & & \\
\hline Rakiplerin eylemlerine hizlıca cevap verilmesi & $0.70 * *$ & & \\
\hline $\begin{array}{l}\text { Rakiplerin stratejilerinin üst yöneticiler tarafindan sürekli } \\
\text { tartış1lmas1 }\end{array}$ & $0.81 * *$ & & \\
\hline Rekabet avantajı için firsatlara odaklanılması & $0.82 * *$ & & \\
\hline Fonksiyonlar arası koordinasyon & & 0.90 & 0.63 \\
\hline Birimler arasında müşteri çağrı merkezinin oluşturulması & $0.73 * *$ & & \\
\hline Önemli bilgilerin departmanlar arasında paylaşılma hızı & $0.82 * *$ & & \\
\hline İşletme stratejisinin tüm departmanlar tarafindan benimsenmesi & $0.86 * *$ & & \\
\hline $\begin{array}{l}\text { Tüm departmanların müşteri değerinin oluşmasına katkıda } \\
\text { bulunması }\end{array}$ & $0.80 * *$ & & \\
\hline İşletme kaynaklarının tüm departmanlar arasında paylaşılması & $0.76 * *$ & & \\
\hline \multicolumn{4}{|c|}{ Uyum iyiliği: $\chi^{2}$ / df =1.58; GFI=95; AGFI=93; NFI=95; CFI= ; RMSEA= .041 } \\
\hline \multicolumn{4}{|c|}{ Örgüt Külttürü } \\
\hline Adhokrasi kültürü & & 0.92 & 0.67 \\
\hline Yöneticilerin girişimcilik, yenilik yapma ve risk almada öncü rolü & $0.80 * *$ & & \\
\hline Yenilik ve gelişime olan bağlılık & $0.82 * *$ & & \\
\hline Yeni kaynaklar elde etme, gelişme ve yeni firsatlar araştırma & $0.79 * *$ & & \\
\hline Özel ve yeni ürünlere sahip olmaya dayalı başarı kriteri & $0.81 * *$ & & \\
\hline Bireyselliği, risk almayı ve yenilikçiliği destekleyen yönetim biçimi & $0.83 * *$ & & \\
\hline Çalışanların iş bitirici ve risk almaya istekliliği & $0.85 * *$ & & \\
\hline Pazar külttürü & & 0.91 & 0.64 \\
\hline Sık1 rekabet etme üzerine kurulan başarı kriterleri & $0.78 * *$ & & \\
\hline Pazar payını/hizmet alanlarını genişletmede rekabetçi davranıșlar & $0.79 * *$ & & \\
\hline Kazanmaya arzulu ve sonuç odaklı yöneticiler & $0.84 * *$ & & \\
\hline Görev, amaç ve hedeflerin ne șekilde olursa olsun başarılması & $0.84 * *$ & & \\
\hline $\begin{array}{l}\text { Sikı rekabeti, hırslı olmayı ve profesyonelliği destekleyen yönetim } \\
\text { biçimi }\end{array}$ & $0.80 * *$ & & \\
\hline İş bitiriciliğe, sonuç odaklılığa ve başarmaya odaklılık & $0.76 * *$ & & \\
\hline Klan kültürü & & 0.90 & 0.62 \\
\hline Yöneticilerin yol gösterici, işleri kolaylaştırıcı rolü & $0.75 * *$ & & \\
\hline $\begin{array}{l}\text { Çalışanlar arasındaki bağlılığa, yüksek güven ve sadakate yapılan } \\
\text { vurgu }\end{array}$ & $0.80 * *$ & & \\
\hline $\begin{array}{l}\text { Yüksek seviyede birlikteliğe, morale ve insan kaynağının gelişimine } \\
\text { verilen önem }\end{array}$ & $0.77 * *$ & & \\
\hline $\begin{array}{l}\text { Takım çalışması, kararlarda fikir birliğini ve çalışların yönetime } \\
\text { katılımı }\end{array}$ & $0.81 * *$ & & \\
\hline $\begin{array}{l}\text { Çalışan gelişimi, takım çalışması ve bağlılığa dayalı başarı } \\
\text { değerlendirme }\end{array}$ & $0.80 * *$ & & \\
\hline Örgütteki aile ortamı ve işletmenin çalışan için özel önemi & $0.81 * *$ & & \\
\hline Hiyerarşi külttürü & & 0.97 & 0.82 \\
\hline Yöneticilerin işleri koordine etme ve önceden belirlenen şekilc & $0.90 * *$ & & \\
\hline
\end{tabular}

devamını sağlama rolü 
İşlerin resmi kural, prosedür ve politikalara uygun olarak

$0.92 * *$

yürütülmesi

Kurumsal devamlılık, istikrar, işlerin etkin, sıkı kontrollü, rutin ve

$0.92 * *$

sorunsuz bir şekilde işlemesi

Çalışanların kendini güvencede hissettiren, risk ve belirsizlikleri

ortadan kaldıran, eşit, uyumlu ve tutarlı ilişkileri destekleyen

yönetim biçimi

Resmi süreçlerin olması çalışanların durumlar karşısında ne yapacağını belirlemesi

Başarının işlerin koordinasyon içinde (resmi) kural ve prosedürlere uygun şekilde yapılmasına dayalı olarak değerlendirilmesi

Oyum iyiliği: $\chi^{2} / \mathrm{df}=1.66 ;$ GFI= .91; $\mathrm{AGFI}=.89 ; \mathrm{NFI}=.94 ; \mathrm{CFI}=.98 ; \mathrm{RMSEA}=.043$

$* * \mathrm{p}<.001, \mathrm{AVE}=$ Average variance extracted, $\chi^{2} / \mathrm{df}=$ Ratio of Chi-square, GFI= Goodness of Fit Index, AGFI=Adjusted GFI, NFI= Normal Fit Index, CFI= Comparative Fit Index, RMSEA= Root Mean Square Error of Approximation

DFA'da ölçüm modellerinin uyumluluğunu değerlendirmek için birçok indeksten yararlanılmaktadır. Bu araştırmada, pazar yönlülük ve örgüt kültürü ölçüm modellerinde elde edilen sonuçları değerlendirmek için kullanılan uyum indeksleri; ki-kare oranı $(<3)$, uyum iyiliği endeksi (GFI> .90), düzeltilmiş uyum iyiliği endeksi (AGFI> .80), normal uyum indeksi (NFI> .90), karşı1laştırmalı uyum indeksi (CFI> .90) ve yaklaşık hataların ortalama karekökü (RMSEA> .08) her iki ölçüm modelinin de iyi uyuma sahip olduğunu göstermektedir (Chin ve Todd, 1995; Klein, 1998; Schermelleh-Engel, Moosbrugger ve Müller, 2003). Dahası, modellerde yer alan değişkenlere ilişkin AVE değerleri Hair ve diğerleri (2009) tarafindan önerilen 0.50 seviyesinin üzerindedir. Ölçüm modellerinde yer alan değişkenlerin güvenilirlik düzeyleri ( $\alpha>0.6)$ oldukça yüksektir.

\section{4. Önerilen Modelin Testi}

Örgüt kültürü ve pazar yönlülük ölçüm modellerinde yer alan değişkenler arasındaki ilişkilerin gücünü ve anlamlılığını bütüncül bir bakış açısıyla test etmek için SEM kullanılmıştır. Tablo 2'de önerilen modelin yapısal sonuçları standart yol katsayıları ile birlikte gösterilmektedir. Yol analizi sonucunda ortaya çıkan uyum indeksleri; $\left(\chi^{2} / \mathrm{df}=1.59(\mathrm{p}<0.01), \mathrm{GFI}=.86, \mathrm{AGFI}=.85 \mathrm{NFI}=.90, \mathrm{CFI}=\right.$ .95 , RMSEA $=0.041)$ test edilmek istenilen modelin uyumunun kabul edilebilir olduğunu göstermektedir.

Tablo 3. YEM Analizi Sonuçları

\begin{tabular}{|c|c|c|c|c|c|c|c|}
\hline \multicolumn{2}{|c|}{ Hipotezler } & \multicolumn{3}{|l|}{ Yol } & \multirow{2}{*}{$\begin{array}{l}\text { B } \\
0.36\end{array}$} & \multirow{2}{*}{$\frac{t \text { t-değeri }}{5.42^{* *}}$} & \multirow{2}{*}{$\begin{array}{l}\text { Sonuçlar } \\
\text { Desteklendi }\end{array}$} \\
\hline $\mathrm{H} 1_{\mathrm{a}}$ & Adhokrasi kültürü & $\rightarrow$ & Müşteri yönlülük & & & & \\
\hline $\mathrm{H} 1_{\mathrm{b}}$ & Pazar kültürü & $\rightarrow$ & Müsteri yönlülük & & 0.27 & $3.94 * *$ & Desteklendi \\
\hline $\mathrm{H} 1_{\mathrm{c}}$ & Klan kültürü & $\rightarrow$ & Müssteri yönlülük & & 0.07 & 1.32 & Reddedildi \\
\hline $\mathrm{H} 1_{\mathrm{d}}$ & Hiyerarşi kültürü & $\rightarrow$ & Müşteri yönlülük & & 0.06 & 1.28 & Reddedildi \\
\hline $\mathrm{H} 2_{\mathrm{a}}$ & Pazar kültürü & $\rightarrow$ & Rakip yönlülük & & 0.38 & $4.74 * *$ & Desteklendi \\
\hline $\mathrm{H} 2_{\mathrm{b}}$ & Adhokrasi külttürü & $\rightarrow$ & Rakip yönlülük & & 0.33 & $5.00 * *$ & Desteklendi \\
\hline $\mathrm{H} 2_{\mathrm{c}}$ & Klan kültürü & $\rightarrow$ & Rakip yönlülük & & -0.14 & $2.40 *$ & Desteklendi \\
\hline $\mathrm{H} 2_{\mathrm{d}}$ & Hiyerarşi kültürü & $\rightarrow$ & Rakip yönlülük & & 0.06 & 1.19 & Reddedildi \\
\hline $\mathrm{H} 3_{\mathrm{a}}$ & Klan külttürü & & $\begin{array}{l}\text { Fonksiyonlar } \\
\text { asyon }\end{array}$ & aras1 & 0.04 & 0.70 & Reddedildi \\
\hline $\mathrm{H} 3_{\mathrm{b}}$ & Hiyerarşi kültürü & $\overrightarrow{\mathrm{koo}}$ & $\begin{array}{l}\text { Fonksiyonlar } \\
\text { asyon }\end{array}$ & aras1 & -0.11 & $3.80 * *$ & Desteklendi \\
\hline
\end{tabular}




\begin{tabular}{|c|c|c|c|c|c|c|}
\hline $\mathrm{H} 3_{\mathrm{c}}$ & Adhokrasi kültürü & $\begin{array}{l}\rightarrow \quad \text { Fonksiyonlar } \\
\text { koordinasyon }\end{array}$ & aras1 & 0.26 & $4.00 * *$ & Desteklendi \\
\hline $\mathrm{H} 3_{\mathrm{d}}$ & Pazar kültürü & $\rightarrow \quad$ Fonksiyonlar & aras1 & 0.35 & $5.04 * *$ & Desteklendi \\
\hline
\end{tabular}

Model uyumu: $\chi^{2} / \mathrm{df}=1.59(\mathrm{p}<0.01) ; \mathrm{GFI}=.86 ; \mathrm{AGFI}=.85 ; \mathrm{NFI}=.90 ; \mathrm{CFI}=.95 ; \mathrm{RMSEA}=0.041$

Not: * $0.05 \mathrm{ve} * * 0.01$ anlamlılık düzeyini ifade etmektedir.

Tablo 3'de gösterildiği gibi otel işletmelerinde adhokrasi kültürünün $(\beta=0.36, \mathrm{p}<0.01)$ ve pazar kültürünün $(\beta=0.27, \mathrm{p}<0.01)$ müşteri yönlülük üzerinde anlamlı bir etkisi vardır. Bunun aksine klan kültürünün ve hiyerarşi kültürünün müşteri yönlülük üzerinde anlamlı bir etkisi yoktur. Bu doğrultuda; H1a ve H1b kabul edilirken H1c ve H1d reddedilmiştir. Analiz sonuçları, otel işletmelerinde pazar kültürünün $(\beta=0.38, \mathrm{p}<0.01)$, adhokrasi kültürünün $(\beta=0.33, \mathrm{p}<0.01)$ ve klan kültürünün $(\beta=-0.14$, $\mathrm{p}<0.05)$ rakip yönlülük üzerinde anlamlı bir etkiye sahip olduğunu göstermektedir. Hiyerarşi kültürünün ise pazar yönlülük üzerinde anlamlı bir etkisi bulunmamaktadır. Dolayısıyla H2a, H2b ve H2c hipotezleri kabul edilmiş H2d hipotezi reddedilmiştir. Son olarak, analiz sonuçları hiyerarşi kültürünün $(\beta=-0.11, p<0.01)$, adhokrasi kültürünün $(\beta=0.26, p<0.01)$ ve pazar kültürünün $(\beta=$ $0.35, \mathrm{p}<0.01$ ) fonksiyonlar arası koordinasyon üzerinde anlamlı bir etkisinin olduğunu göstermektedir. Clan kültürünün ise fonksiyonlar arası koordinasyon üzerinde anlamlı bir etkisi yoktur. Bu kapsamda, H3b, H3c ve H3d kabul edilirken H3a reddedilmiştir. Şekil 3'de yapısal eşitlik modellemesi yol analizi sonuçlarının özeti gösterilmektedir.

\section{SONUÇ VE ÖNERÍLER}

Türk otel endüstrisinin karşı karşıya olduğu belirsizlikler ve rekabet koşulları, otel işletmelerini müşterilerin istek ve ihtiyaçlarına rakiplerinden daha iyi cevap verebilmek için her zamankinden daha fazla pazar yönlü olmaya zorlamaktadır. Otel işletmelerinde pazar yönlülük, hedef müşterilerin istek ve ihtiyaçlarındaki değişimleri izleme, bu değişimleri yönlendiren çevresel dinamiklere uyum ve hizmet sunum sürecinin her aşamasında üstün müşteri değeri yaratılmasını ifade etmektedir. Müşteri bilgi ve duyarlılık düzeyinin yüksek olduğu otel endüstrisinde işletmelerin müşteri istek ve ihtiyaçlarına ilişkin pazar bilgisine ulaşmak ve onlara üstün hizmet sunmak örgütün sahip olduğu kültürle ilişkilidir. 
Şekil 2. YEM Yol Analizi Sonuçları

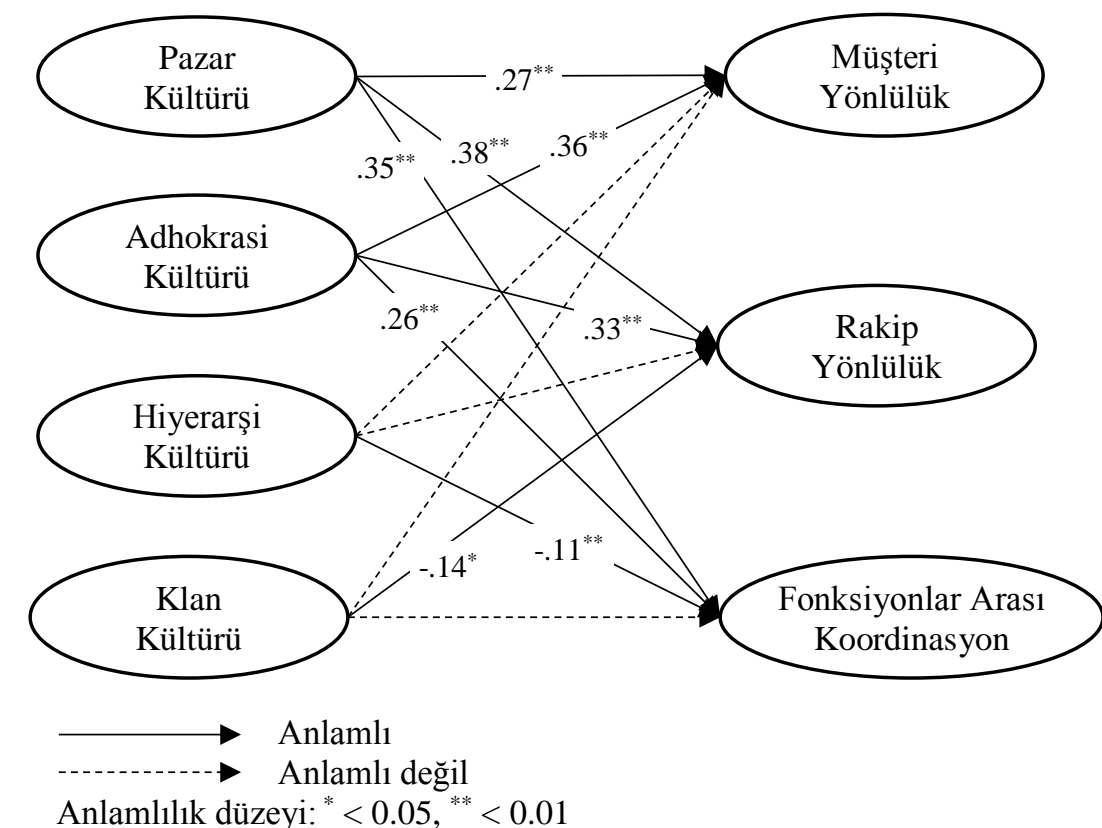

Bir işletmenin sahip olduğu kültür, işletme çalışanlarına birbirleriyle, müşterilerle ve diğer paydaşlarla nasıl bir etkileşim kurmaları gerektiği noktasında rehberlik etmekte ve onların tutum ve davranışlarını yönlendirmektedir. Hizmet işletmelerinde personelin tutum ve davranışları hizmet kalitesi düzeyinin belirleyicisi olduğundan örgütün sahip olduğu kültür, işletmelerin pazar yönlülük düzeyini etkilemektedir. Wei ve diğerleri (2017) otel işletmelerinde çalışanların hata yönetim kültürünün müşterilerin bağl1lık davranışları üzerinde pozitif bir etkisinin olduğu ortaya koymuştur. Pazar odaklı örgüt kültürü oluşturamayan işletmelerin çevresel değişkenlere ya da rakip eylemlerine karşı uygulamış oldukları stratejiler kısa vadede karlılığa katkı sağlasa da uzun vadede hedef pazarı tanımlayamama ve hedef pazarın istek ve ihtiyaçlarına cevap verememe riskini beraberinde getirmektedir. Civelek (2016) İstanbul' daki beş yıldızlı otel işletmelerinde yapmış olduğu araştırmada, işletmelerin çoğunun müşteri merkezli yönetim sürecini başlatacak ve sürdürebilecek bir işletme kültürüne sahip olmadıklarını ve ürün veya hizmetlerini kimlere pazarladıklarını tam olarak bilmediklerini tespit etmiştir.

$\mathrm{Bu}$ araştırma, beş yıldızlı otel işletmeleri özelinde hangi örgüt kültürünün işletmelerin pazar yönlülüğünü daha fazla desteklediğini incelemek amacıyla gerçekleştirilmiştir. Analiz sonuçları, beklendiği gibi otel işletmelerinde adhokrasi ve pazar kültürünün işletmelerin müşteri yönlülügü üzerinde etkili olduğunu ve adhokrasi kültürünün müşteri yönlülüğü pazar kültüründen daha fazla etkilediğini göstermektedir. Bu sonuç, Desphande ve diğerleri (1993) ve Matin ve diğerleri (2009) tarafından ortaya konulan örgüt kültürünün müşteri yönlülük üzerinde etkili olduğu yönündeki bulguları desteklemektedir. Bunun yanı sıra örgüt içi süreçlere odaklı klan kültürünün ve hiyerarşi kültürünün müşteri yönlülük üzerinde anlamlı bir etkisinin olmadığı belirlenmiştir. Bu sonuç, Appiah-Adu ve Blankson (1998) tarafından ifade edilen hiyerarşi ve klan kültürünün çevresel değişimlere daha az 
duyarlı olduklarından müşteri istek ve ihtiyaçlarını takip etmede adhokrasi ve pazar kültürüne göre yetersiz oldukları görüşü ile örtüşmektedir.

Analiz sonuçları, otel işletmelerinde rakip yönlülüğü en fazla destekleyen örgüt kültürünün rekabet avantajı ve pazar liderliği gibi karakteristik özelliklere sahip pazar kültürü olduğunu ve bunu yenilikçilik ve girişimcilik özellikleri ile adhokrasi kültürünün izlediğini göstermektedir. Elde edilen bulgular, Deshpande ve diğerleri (1993) tarafindan ifade edilen klan kültüründe geleneklere olan bağlılığın değişen pazar koşullarına odaklanmada önemli bir eksiklik olduğu görüşünü desteklemektedir. Analiz sonucunda, klan kültürünün otel işletmelerinde rakip yönlülüğü negatif olarak etkilediği tespit edilmiştir. Buna ek olarak, hiyerarşi kültürünün otel işletmelerinin rakip yönlülüğü üzerinde anlamlı bir etkisinin olmadığı belirlenmiş̧tir. Bu sonuçlar, Appiah-Adu ve Blankson (1998) ve Harrington ve Guimaraes (2005) tarafından dile getirilen dış çevreye odaklı örgüt kültürlerinin rakip yönlülüğü iç süreçlere odaklı örgüt kültürlerinden daha fazla desteklediği görüşüyle uyumludur.

Fonksiyonlar arası koordinasyon açısından ele alındığında, beklenin aksine örgüt içi süreçlere odaklı kültür tiplerinin otel işletmelerinde fonksiyonlar arası koordinasyonu dış çevreye odaklı kültür tiplerinden daha az desteklediği belirlenmiştir. Otel işletmelerinde fonksiyonlar arası koordinasyonu en fazla destekleyen örgüt kültürü tipi pazar kültürüdür. Pazar kültürünü bireyselliğin ve özgürlügün teşvik edildiği adhokrasi kültürü izlemektedir. Bunun aksine, görev verimliliğine odaklı hiyerarşi kültürünün ise otel işletmelerinde fonksiyonlar arası koordinasyonu negatif yönde etkilediği tespit edilmiştir. Son olarak, takım çalışması, katılım ve uyum gibi karakteristik özelliklere sahip klan kültürünün fonksiyonlar arası koordinasyon üzerinde anlamlı bir etkisinin olmadığı sonucuna ulaşılmıştır.

Araştırma sonucunda, genel olarak otel işletmelerinde örgüt kültürünün işletmelerin pazar yönlülüğü üzerinde anlamlı bir etkiye sahip olduğu belirlenmiştir. Örgüt kültürü tipleri özel olarak incelendiğinde ise otel işletmelerinde pazar yönlülüğü en fazla destekleyen örgüt kültürünün pazar kültürü olduğu sonucuna ulaşılmıştır. Pazar kültürünün ardından pazar yönlülüğü en fazla destekleyen ikinci örgüt kültürü tipi ise adhokrasi kültürüdür. Dolayısıyla pazar yönlülük düzeylerini artırmak isteyen otel işletmelerine pazar kültürünün karakteristik özellikleri olan rekabetçilik, pazara nüfuz etme ve pazar payı ve adhokrasi kültürünün yenilikçilik, girişimcilik ve sorumluluk alma gibi karakteristik özelliklerini örgüt kültürlerine empoze etmeleri önerilmektedir. Araştırma sonuçları, örgüt içi süreçlere odaklı kültür tiplerinin işletmelerin pazar yönlülük düzeylerini negatif yönde etkilediğini göstermektedir. Bu bakımdan klan kültürüne ve hiyerarşi kültürüne sahip otel işletmeleri yöneticileri, turizm pazarında yaşanan değişimleri sıkı bir şekilde takip etmeli ve örgüt içerisindeki bağlılık, uyum, resmileşme ve kontrol gibi karakteristik özellikleri örgütün bu değişimlere adaptasyonunu hızlandıracak şekilde yeniden dizayn etmeleri önerilmektedir. Bu araştırma sonuçları beş yıldızlı 20 otel işletmesinden elde edilen bulgularla sınırlıdır. Yapılacak araştırmalarda, konaklama endüstrisinin diğer parçaları üzerine odaklanılabilir. Buna ek olarak, otel işletmelerinde örgüt kültürünün ve pazar yönlülügün işletme ve müşteri performansına etkileri araştırılabilir. 


\section{KAYNAKÇA}

Adler, P. S. ve Borys, B. (1996) “Two Types of Bureaucracy: Enabling and Coercive”, Administrative Science Quarterly, 41 (1): 61-89.

Adler, P. S., Goldoftas, B. ve Levine, D. I. (1999) “Flexibility versus Efficiency? A Case Study of Model Changeovers in the Toyota Production System”, Organization Science, 10 (1): 43-68.

Agarwal, S., Erramilli, M. K. ve Dev, C. S. (2003). "Market Orientation and Performance in Service Firms: Role of Innovation”, Journal of Services Marketing, 17 (1): 68-82.

Agbejule, A. (2011) "Organizational Culture and Performance: The Role of Management Accounting System", Journal of Applied Accounting Research, 12 (1): 74-89.

Appiah-Adu, K. ve Blankson, C. (1998) "Business Strategy, Organizational Culture, and Market Orientation”, Thunderbird International Business Review, 40 (3): 235-256.

Asree, S., Zain, M. ve Razalli, M. R. (2010). "Influence of Leadership Competency and Organizational Culture on Responsiveness and Performance of Firms", International Journal of Contemporary Hospitality Management, 22 (4): 500-516.

Bilgin, Y., Çatı, K. ve Öncü, M. A. (2016) “Otel İşletmelerinin Pazarlama Anlayışları Üzerine Nitel Bir Araştırma", Bartın Üniversitesi İ.İ.B.F. Dergisi, 7 (14): 241-285.

Bowen, J. T. ve Chen, S. L. (2001) "The Relationship between Customer Loyalty and Customer Satisfaction”, International Journal of Contemporary Hospitality Management, 13 (5): 213-217.

Brady, M. K. ve Cronin, J. J. (2001) "Some New Thoughts on Conceptualizing Perceived Service Quality: A Hierarchical Approach", Journal of Marketing, 65 (3): 34-49.

Camerer, C. ve Vepsalainen, A. (1988) "The Economic Efficiency of Corporate Culture", Strategic Management Journal, 9 (1): 115-126.

Cameron, K. S. ve Quinn, R. E. (2006) "Diagnosing and Changing Organizational Culture: Based on the Competing Values Framework", (Rev. ed.) San Francisco, CA: Wiley (Jossey Bass).

Cameron, K. ve Quinn, R. E. (1999) "Diagnosing and Changing Organizational Culture: Based on the Competing Values Framework", Reading: Addison-Wesley.

Cheung, S. O., Wong, P. S. P. ve Wu, A. W. Y. (2011) “Towards an Organizational Culture Framework in Construction", International Journal of Project Management, 29 (1): 33-44.

Chin, W. C. ve Todd, P. A. (1995) "On the Use, Usefulness and Ease of Use of Structural Equation Modeling in MIS Research: A Note of Caution”, MIS Quarterly, 19 (2): 237-246. 
Cho, I., Kim, J. K. K., Park, H. ve Cho, N. H. (2013) “The Relationship between Organisational Culture and Service Quality through Organisational Learning Framework", Total Quality Management \& Business Excellence, 24 (7-8): 753-768.

Civelek, A. (2016) "Konaklama işletmelerinde Müşteri İlişkileri Yönetiminin İşletme Performansına Etkisi: 5 Yıldızlı Oteller Üzerine Bir Uygulama”, Sosyal Bilimler Meslek Yüksekokulu Dergisi, 19 (2): 233-252.

Daft, R. L. (2015). “Örgüt Kuramları ve Tasarımını Anlamak”, (Çev. Kollektif), Ankara, Nobel Yayın Dă̆ıtım.

Dastmalchian, A., Lee, S. ve Ng, I. (2000) “The Interplay between Organizational and National Cultures: A Comparison of Organizational Practices in Canada and South Korea Using the Competing Values Framework", The International Journal of Human Resource Management, 11 (2): 388-412.

Denison, D. R. (1984) “Bringing Corporate Culture to the Bottom Line”, Organizational Dynamics, 13 (2): 4-22.

Deshpande, R., Farley, J. U. ve Webster, F. E. (1993) “Corporate Culture, Customer Orientation, and Innovativeness in Japanese Firms: A Quadrad Analysis", Journal of Marketing, 57 (1): 23-37.

Deshpande, R. ve Webster, F. E. (1989) “Organizational Culture and Marketing: Defining the Research Agenda", The Journal of Marketing, 53 (1): 3-15.

Dwyer, L. Teal, G. ve Kemp, S. (1998) “Organisational Culture \& Strategic Management in A Resort Hotel”, Asia Pacific Journal of Tourism Research, 3 (1): 27-36.

Egeren, M. V. ve O'Connor, S. (1998) "Drivers of Market Orientation and Performance in Service Firms", Journal of Services Marketing, 12 (1): 39-58.

Eren, D. (2003) “Otel İşletmeciliğinde Pazarlama Anlayışı ve Pazar Yönlülük: Türkiye'de Faaliyet Gösteren Dört ve Beş Yıldızlı Otellerde Yapılan Bir Araştırma ve Sonuçları”, Mersin: Mersin Üniversitesi, Sosyal Bilimler Enstitüsü Turizm İşletmeciliği ve Otelcilik Anabilim Dalı, Mersin.

Fang, S. R., Chang, E., Ou, C. C. ve Chou, C. H. (2014) "Internal Market Orientation, Market Capabilities and Learning Orientation”, European Journal of Marketing, 48 (1/2): 170-192.

Farrell, M. A. (2000) "Developing a Market-Oriented Learning Organisation”, Australian Journal of Management, 25 (2): 201-223.

Fiol, C. M. ve Lyles, M. A. (1985) “Organizational learning”, Academy of Management Review, 10 (4): 803-813.

Gagliardi, P. (1986) “The Creation and Change of Organizational Cultures: A Conceptual Framework”, Organizational Studies 7 (2): 117-134. 
George, G., Sleeth, R. G. ve Siders, M. A. (1999) “Organizing Culture: Leader Roles, Behaviors, And Reinforcement Mechanisms", Journal of Business and Psychology, 13 (4): 545-560.

Gray, B., Matear, S., Boshoff, C. ve Matheson, P. (1998) "Developing A Better Measure of Market Orientation", European Journal of Marketing, 32 (9/10): 884-903.

Hair, J. F., Black, W. C., Babin, B. J. ve Anderson, R. E. (2009) “Multivariate data analysis", Upper Saddle River, NJ: Prentice Hall.

Han, H. ve Verma, R. (2012) "The Effect of Corporate Culture and Strategic Orientation on Financial Performance: An Analysis of South Korean Upscale and Luxury Hotels", Cornell Hospitality Report, 12 (4): 6-14.

Harrington, S. J. ve Guimaraes, T. (2005) "Corporate Culture, Absorptive Capacity and IT Success", Information and Organization, 15 (1): 39-63.

Izquierdo, C. C., Cillán, J. G. ve Gutierrez, S. S. M. (2005) “The Impact of Customer Relationship Marketing on the Firm Performance: A Spanish Case", Journal of Services Marketing, 19 (4): 234-244.

Jaworski, B. J. ve Kohli, A. K. (1993) "Market Orientation: Antecedents and Consequences”, Journal of Marketing 57 (3): 53-70.

Jayawardhana, A. A. K. K., Silva, S. D.ve Athauda, A. M. T. P. (2013) "Business Strategy, Market Orientation and Sales Growth in Hotel Industry of Ancient Cities in Sri Lanka”, Tropical Agricultural Research, 24 (3): 228-237.

Jogaratnam, G. (2017) "How Organizational Culture Influences Market Orientation and Business Performance in the Restaurant Industry", Journal of Hospitality and Tourism Management, 31: 211-219.

Kalaycı, Ş. (2016) “SPSS Uygulamalı Çok Değişkenli İstatistik Teknikleri”, 8. Baskı, Ankara, Dinamik Akademi.

Kandampully, J. ve Suhartanto, D. (2000) "Customer Loyalty in the Hotel Industry: The Role of Customer Satisfaction and Image", International Journal of Contemporary Hospitality Management 12 (6): 346-351.

Kim, G. S. (2007) “The Service Recovery Strategies, Customer Satisfaction, Customer Loyalty”, Asian Journal on Quality, 8 (1): 76-86.

Kim, M., Choi, L., Knutson, B. J. ve Borchgrevink, C. P. (2017) "Hotel employees' Organizational Behaviors from Cross-National Perspectives", International Journal of Contemporary Hospitality Management, 29 (12): 3082-3100. 
Kline, R. B. (1998) “Principles and practice of structural equation modeling” (2nd ed.), New York, NY: Guilford.

Kohli, A. K. ve Jaworski, B. J. (1990) "Market Orientation: The Construct, Research Proposition and Managerial Implication”, Journal of Marketing, 54 (2): 1-18.

Kosuge, R. (2007) “Internal Effects of Customer Contact within Service Organizations: Implications for Developing a Customer-oriented Organizational Culture", Annals of Business Administrative Science, 6: 1-14.

Kotler, P., Armstrong, G., Saunders, J. ve Wong, V. (1999) "Principles of Marketing. Milan”, Prentice Hall, Europe.

Lawrence, P. R. ve Lorsch, J. W. (1967) “Organization and Environment; Managing Differentiation and Integration", Harvard Business School Press.

Lehtinen, U. ve Lehtinen, J. R. (1991) “Two Approaches to Service Quality Dimensions”, The Service Industries Journal, 11 (3): 287-303.

Louis, M. R. (1980) "Surprise and Sense Making: What Newcomers Experience in Entering Organizational Settings", Administrative Science Quarterly, 25 (2): 226-251.

Lund, D. B. (2003) "Organizational Culture and Job Satisfaction", Journal of Business \& Industrial Marketing, 18 (3): 219-236.

Matin, H. Z., Jandaghi, G., Khanifar, H. ve Heydari, F. (2009) “Designing A Competent Organizational Culture Model for Customer Oriented Companies", African Journal of Business Management, 3 (7): 281-293.

McClure, R. E. (2010) “The Influence of Organizational Culture and Conflict on Market Orientation”, Journal of Business \& Industrial Marketing, 25 (7): 514-524.

Mushtaq, A. L., Fayyaz, A.S. ve Tanveer, A. (2013) “Organizational Culture in Hotel Industry: Perceptions and Preferences among Staff', Advances in Management, 6 (5): 55-60.

Narver, J. C. ve Slater, S. F. (1990) "The Effect of A Market Orientation on Business Profitability", Journal of Marketing 64: 21-35.

Otache, I. ve Mahmood, R. (2015) "Market Orientation and Firm Performance: The Role of Organizational Culture and External Environment - A Proposed Model”, International Business Management. 9 (5): 816-823.

Oz, M., Kaya, F. ve Ciftci, I. (2015) "Evaluating the Organizational Culture Types of the 5-Star Hotel's in Istanbul in terms of the Cameron \& Quinn Competing Values Model", Journal of Yasar University, 10 (40): 6684-6691. 
Parasuraman, A., Zeithaml, V. A. ve Berry, L. L. (1985) “A Conceptual Model of Service Quality and Its Implications for Future Research", The Journal of Marketing, 49 (4): 41-50.

Peng, C. ve George, R. T. (2011) “The Effect of Inter-functional Coordination on Organizational Commitment in Hotel Industry", http://scholarworks.umass.edu/cgi/viewcontent.cgi?article=1260\&context=gradconf_hospitality. Son erişim tarihi: 11.01.2018.

Pitt, L., Caruana, A. ve Berthon, P. R. (1996) "Market Orientation and Business Performance: Some European Evidence", International Marketing Review 13 (1): 5-18.

Plinke W. (2015) “The Core Concept of Marketing Management”, M. Kleinaltenkamp et al. (eds.), Fundamentals of Business-to-Business Marketing, pp. 77-127. Springer Texts in Business and Economics, DOI 10.1007/978-3-319-12463-6_2.

Pulendran, S., Speed, R. ve Widing, R. E. (2003) “Marketing Planning, Market Orientation and Business Performance", European Journal of Marketing 37 (3/4): 476-497.

Quinn, R. E. ve Cameron, K. (1983) “Organizational Life Cycles and Shifting Criteria of Effectiveness: Some Preliminary Evidence”, Management Science, 29 (1): 33-51.

Quinn, R. E. ve Rohrbaugh, J. (1983) “A Spatial Model of Effectiveness Criteria: Towards a Competing Values Approach to Organizational Analysis”, Management Science, 29: 263-377.

Rodrigues, A. C. ve Caetano, A. (2013) “A Competing Values Framework Approach on Growth and Performance in Micro Firms”, In Entrepreneurship Summer University at ISCTE-IUL, Lison.

Schein, E. H. (1990) “Organizational culture”, American Psychologist, 45 (2): 109-119.

Schermelleh-Engel, K., Moosbrugger, H. ve Müller, H. (2003) “Evaluating the Fit of Structural Equation Models: Tests of Significance and Descriptive Goodness-of-Fit Measures", Methods of Psychological Research, 8 (2): 23-74.

Shehu, A. M. ve Mahmood, R. (2014) "The Relationship between Market Orientation and Business Performance of Nigerian SMEs: The Role of Organizational Culture", International Journal of Business and Social Science, 5 (9): 159-168.

Shoham, A., Rose, G. M. ve Kropp, F. (2005) “Market Orientation and Performance: A Meta-Analysis”, Marketing Intelligence \& Planning 23 (5): 435-454.

Sin, Leo Y. M., Tse, Alan C. B., Heung, Vincent C. S. ve Yim, Frederick H. K. (2005) “An Analysis of The Relationship between Market Orientation and Business Performance in The Hotel Industry", Hospitality Management 24: 555-577.

Slater, S. F. ve Narver, J. C. (1994) “Market Orientation, Customer Value, and Superior Performance”, Business Horizons 37 (2): 22-28. 
Smircich, L. (1983) "Concepts of Culture and Organizational Analysis", Administrative Science Quarterly, 28 (3): 339-358.

Tajeddini, K. (2011) “Market Orientation and Business Performance: Evidence from The Hotel İndustry in Germany", International Journal of Leisure and Tourism Marketing 2 (3): 232-247.

Taşgit, Y. E., Ergün, E. ve Bayat, M. (2015) “Otel İşletmelerinin İş Çevresi Özelliklerinin Kurum Kültürü Türleri Üzerindeki Etkisi”, Seyahat ve Otel İşletmeciliği Dergisi, 12 (2): 92-120.

Tsiotsou, R. H. (2010) "Delineating the Effect of Market Orientation on Services Performance: A Component-Wise Approach”, The Service Industries Journal, 30 (3): 375-403.

Wang, C. H., Chen, K. Y., Chen, S. C. (2012) "Total Quality Management, Market Orientation and Hotel Performance: The Moderating Effects of External Environmental Factors", International Journal of Hospitality Management 31: 119-129.

Wei, W., Hua, N., Fu, X. ve Guchait, P. (2017) “The Impacts of Hotels’ Error Management Culture on Customer Engagement Behaviors (CEBs)", International Journal of Contemporary Hospitality Management, 29 (12): 3119-3137.

Youngblood, M. D. (2000) “Winning Cultures for the New Economy”, Strategy \& Leadership, 28 (6): 4-9.

Zhou, K. Z. Brown, J.R. ve Dev, C. S. (2009) "Market Orientation, Competitive Advantage, and Performance: A Demand-Based Perspective”, Journal of Business Research 62: 1063-1070. 